Relations industrielles

Industrial Relations

\title{
Krasas Rogers, Jackie, Temps: The Many Faces of the Changing Workplace
}

\section{Leah F. Vosko}

Volume 55, numéro 4, 2000

URI : https://id.erudit.org/iderudit/051362ar

DOI : https://doi.org/10.7202/051362ar

Aller au sommaire du numéro

Éditeur(s)

Département des relations industrielles de l'Université Laval

ISSN

0034-379X (imprimé)

1703-8138 (numérique)

Découvrir la revue

Citer ce compte rendu

Vosko, L. F. (2000). Compte rendu de [Krasas Rogers, Jackie, Temps: The Many Faces of the Changing Workplace]. Relations industrielles / Industrial Relations, 55(4), 779-780. https://doi.org/10.7202/051362ar

Tous droits réservés @ C Département des relations industrielles de l'Universite Laval, 2000
Ce document est protégé par la loi sur le droit d'auteur. L’utilisation des services d'Érudit (y compris la reproduction) est assujettie à sa politique d'utilisation que vous pouvez consulter en ligne.

https://apropos.erudit.org/fr/usagers/politique-dutilisation/ 


\section{Temps: The Many Faces of the Changing Workplace}

by Jackie KRASAS ROGERS, Ithaca, N.Y.: Cornell University Press, 2000, 247 pp., ISBN 0-8014-3638-9 (cloth) and ISBN 0-8014-8662-9 (paper).

What are we to make of recent changes in the American labour market? What types of employment are replacing the full-time, full-year job and how are these "new" forms of employment gendered and racialized? In her recent book Temps: The Many Faces of the Changing Workplace, Jackie Krasas Rogers addresses these questions. Rogers' book is an in-depth exploration of the day-to-day experiences of two distinct groups of temp workers - clerical temps and temporary lawyers which provides insight into an increasingly common form of non-standard employment in the United States, one that is marked by growing occupational diversity.

The central objective of this book is to construct a nuanced picture of temporary work as "something more than a subjection of workers who can be summed up by the outdated idea of the 'Kelly Girl'" (p. 2). While distancing her inquiry from this stereotype, Rogers places gender and race at the centre of her analysis in attempting to explain job hierarchies inside the world of temporary world and the growing plurality of non-standard forms of employment lacking security, stability, and the higher levels of remuneration associated with standard work. Unlike previous scholarship on the subject, including works by Robert Parker (1994) and George Gonos (1994), which provide portraits of the temporary help industry, and work by Kevin Henson (1996), which offers a rich ethnographic account of temping, Rogers incorporates recent feminist literature on the labour process and worker resistance to deepen her account. Based on this approach, she argues that there is a critical need to compare temporary work across different occupations because only this type of comparative inquiry will enable scholars to understand fully the meaning of the temporary in temporary work. The resulting study describes the nature and effects of the growing income and occupational polarization among temp workers, and substantiates claims that the rise of the temporary employment relationship threatens to de-stabilize standard employment relationships across the occupational spectrum and simultaneously deepen gendered and racialized job hierarchies in the labour market.

Methodologically, Rogers relies primarily on participant observation and open-ended interviews with temp workers and agency managers. The book is therefore driven by an analysis grounded in workers' experiences. Chapter 2 addresses the social construction of skill among clerical temps arguing that, in the case of this type of temporary work, a change in the social organization of work encourages changes in social perceptions of skill. Succeeding chapters analyze organization and control in temporary clerical work (Chapter 3), resistance among clerical temps (Chapter 4) and subjectivity in clerical temp work (Chapter 5). Together, Chapters 3-5 explore both the means by which temporary help agencies secure compliance and cooperation among clerical temps and the complex ways in which these temp workers express their agency. Whereas the first two-thirds of the book examines the situation of temporary clerical workers, who represent the majority of Rogers' informants, Chapter 6 explores the proliferation of temp work among lawyers with the aim of explaining what happens when temporary work - historically identified with women enters the traditionally male domain of law (p. 132). In turn, Chapter 7 compares the labour process, as well as the organization of control, in temporary 
legal work and clerical work, probing how these forms of temp work are differentially gendered.

The central strengths of this book are threefold. First, Rogers' discussion of the social construction of skill in temp work and its relationship to gendered job hierarchies is an important contribution to the labour process literature. In Chapter 2 , she effectively combines a discussion of the process of deskilling in clerical work and the devaluation of the skills held by temps to reconcile opposing reports on the effects of the growth of temp work in traditional workplaces. Second, the discussion in Chapter 4 of how the gendered organization of temp work shapes workers' struggle for control in the workplace goes beyond understanding of worker resistance, especially those that take the unionized male industrial worker as the norm. Third, the comparison between lawyers working as temps and clerical temps in Chapters 6 and 7 is arguably the strongest part of the book. By investigating these two growing, but widely divergent types of temp work, Rogers ably demonstrates that two occupationally distinct forms of temp work can be differentially feminized. In both occupational categories, women dominate the ranks of temporary workers. However, the history of clerical work from the beginning of the twentieth century, which was marked by the declining presence of men and growing mechanization, shapes its precarious and feminized contemporary form. In contrast, although legal temping is gendered and women temp lawyers are at the bottom of the occupational ladder in the legal profession, temp lawyers exercise a much higher degree of control and autonomy than their counterparts performing clerical work.

Given its emphasis on presenting detailed sketches of two types of temp work, this book necessarily has limitations. Indeed, Rogers recognizes that it is difficult to generalize from her case study since her sample is quite small. But there is a larger and more general weakness in Rogers' account. The analysis in the book is undermined by the lack of attention paid to two related factors shaping the gendered dynamics of temp work: the regulatory struggles at play outside the workplace and the salience of class, combined with race and gender, in the operation of the temporary employment relationship. Combined with her extensive field research, a deeper political economy analysis situating temp work in the context of changing employment relationships that characterize the contemporary labour market - would have allowed Rogers to reach a more definitive conclusion about the nature of temp work across the growing spectrum of occupations.

Despite these limitations, Temps: The Many Faces of the Changing Workplace is a welcome addition to the growing body of literature on temp work, offering new insights into the operation of gender and race in the labour process. It addresses new and pressing questions raised by the growing occupational diversity within the expanding forms of non-standard employment, fundamental questions confronting labour studies and industrial relations scholars today.

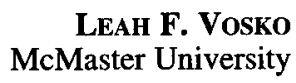
McMaster University 